\title{
The Arab Awakening and US counterterrorism in the Greater Middle East: A Missed Opportunity
}

\section{by Eugenio Lilli}

\section{(cc) $\mathrm{BY}$}

This work is licensed under a Creative Commons Attribution 3.0 License.

\begin{abstract}
In 2011, the Arab Awakening offered an opportunity to the Obama administration to advance the US interest to counter terrorism in the Greater Middle East without compromising its commitment to the promotion of democracy. As of early 2015, however, with the exception of still-hopeful Tunisia, democracy has not made any significant progress in Middle Eastern countries. Additionally, old and new regional extremist groups have become increasingly active. How did the Obama administration miss the opportunity offered by the Arab Awakening? What actions could the United States take to reverse current unfavorable trends and advance US policies of counterterrorism and democratization in the region?
\end{abstract}

Keywords: Counterterrorism, Democracy Promotion, US Foreign Policy, Arab Awakening, The Middle East, Barack Obama

\section{Introduction}

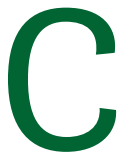

ounterterrorism has long been a core US strategic interest in the Greater Middle East. [1] Policies of counterterrorism have sometimes conflicted with US ideal interests in the region, such as the promotion of democratic values. Highly controversial US counterterrorism practices after 9/11 are a case in point. In 2011, the Arab Awakening offered an opportunity to the Barack Obama administration to advance the US interest to counter terrorism without compromising its public commitment to democracy promotion. In fact, in 2011, popular movements across the Greater Middle East demanded reforms that were in line with US ideals and values. Meanwhile, the overwhelmingly peaceful nature of the protests seemed to have fatally discredited the extremists' argument that only violence could achieve meaningful change in the region. As of early 2015, however, with the exception of still-hopeful Tunisia, democracy has not made any significant progress in Middle Eastern countries. Additionally, old and new regional extremist groups have become increasingly active. This article analyzes how the Obama administration missed the opportunity offered by the Arab Awakening, and it suggests some actions that the United States could take to reverse current unfavorable trends and advance US policies of counterterrorism and democratization in the Greater Middle East.

\section{Conflicting US national interests in the Greater Middle East}

The pursuit of the national interest is a key concept in foreign policy. In 1996, a study conducted by foreign policy experts and former and prospective members of US administrations concluded that "national 


\section{Journal of Terrorism Research}

interests are the fundamental building blocks in any discussion of foreign policy."(The Commission on America's National Interests, 1996, p. 13) Reinforcing this argument, academic Gideon Rose writes that a state's national interest in foreign policy consists of "the goals or preferences that guide the country's external behavior."(Rose, 1998, p. 152) Scholars and foreign policy practitioners alike generally acknowledge the strong connection that exists between the national interest and a state's foreign policy.

Nevertheless, when it comes to the specific identification of Rose's goals and preferences, the above general consensus weakens and opinions start to diverge significantly. In fact, as noted in a US Central Intelligence Agency study, "national interests are not absolutes."(Fulton T. Armstrong, 2002) Some national interests ostensibly enjoy universal support such as the defense of a country's territorial integrity from foreign attack or the protection of its citizens. Other national interests, instead, may be dependent on what the incumbent administration deems to represent the current most pressing concerns. For example, the Obama administration's perceived need in 2009 for a pronounced "pivot" of US foreign policy toward Asia. Moreover, national goals and preferences in foreign policy may be influenced by unexpected -or Black Swanevents that have the potential to markedly alter an administration's previous priorities. Tellingly, the 9/11 terrorist attacks against the United States suddenly elevated hitherto neglected Afghanistan to one of the top priorities in the foreign policy agenda of the George W. Bush administration.

The task of identifying a country's goals and preferences in foreign policy is made harder by the fact that the national interest commonly includes concerns extending beyond a single policy area. Scholar Samuel Huntington describes this aspect of the national interest as follows: "National interests usually combine security and material concerns, on the one hand, and moral and ethical concerns, on the other."(Huntington, 1997, p. 35) These general considerations on the concept of the national interest also apply to the specific case of the United States. Indeed, academic Joseph Nye Jr. maintains that, with regard to US foreign policy, "the national interest is simply the set of shared priorities regarding [US] relations with the rest of the world." Moreover, Nye explains that the US national interest "is broader than strategic interests [...] The American people clearly think that their interests include certain values and their promotion abroad.'(Nye, 1999) Drawing on Huntington's and Nye's insights, in this article we distinguish two major clusters of interests within the broader US national interest: strategic interests and ideal interests. On the one hand, US strategic interests include mainly security, geo-political, economic, and commercial concerns. On the other hand, US ideal interests generally refer to the promotion of national ideology, defined here as a coherent and organic system of beliefs, symbols, and values.

In their relations with the outside world, US administrations have continuously wrestled to find an acceptable balance between the protection of US strategic interests and the promotion of US ideal interests. Tensions among different US national interests have punctuated the history of the country. There is an extensive literature arguing that such tensions have been especially frequent, although not unique, in the US foreign policy toward the Greater Middle East. Former US Ambassador Mark Indyk and others contend that, when framing US Middle East policies, "every [US] president since Franklin Roosevelt has struck that balance in favor of the [strategic] national interest, downplaying the promotion of America's democratic values because of the region's strategic importance."(Indyk, Lieberthal, \& O’Hanlon, 2012, p. 142) In a similar fashion, Middle East expert Kenneth Pollack holds that "in the Middle East, Washington set [the promotion of ideal interests] aside, both because it feared that their application to the Middle East would produce Arab States inimical to American interests and because we [the United States] always had immediate concerns in the region that required the cooperation of America's [autocratic] Arab allies."(Pollack, 2011, p. 8) 


\section{Journal of Terrorism Research}

This article focuses its attention on the relationship between two particularly important US national interests in the Greater Middle East: the strategic interest to counter terrorism and the ideal interest to advance democratic values. Democracy promotion and counterterrorism are both core US national interests. They are consistently described as such in official documents issued by the US government, including in the Obama administration's National Security Strategy 2015.(Obama, 2015) Moreover, democracy promotion and counterterrorism in the Greater Middle East are longstanding US concerns. Arguably, the interest of the United States in advancing democratic values in the region started in the early $20^{\text {th }}$ century when US President Woodrow Wilson announced his commitment to make the world "safe for democracy" and actively engaged in the post-WWI peace negotiations.(Wilson, 1917) The US interest in Middle Eastern terrorism, instead, became significant in the wake of the Arab-Israeli War of 1967, when a number of Palestinian groups radicalized and began to resort to terrorist tactics, including airplane hijackings, hostage takings, and bombings, to target US citizens and assets.(Naftali, 2004)

If we adopt a long-term view, the objectives of combating terrorism and advancing democratic values seem to converge. In fact, a popular argument maintains that democratic forms of government provide people with peaceful channels to express their grievances and achieve change, therefore reducing the appeal of resorting to violence and terrorist tactics. According to this view, the implementation of democratic reforms would eventually lead to less terrorism.(Bush, 2006) However, transitions to democratic forms of government need time to bear fruit, whereas, as Pollack points out, the United States is generally confronted by "immediate concerns" in the Greater Middle East that require a quick response. Consequently, US officials tend to adopt a short-term view on issues of Middle Eastern terrorism that could raise tensions between the objectives of countering terrorism and promoting democracy. These tensions include the competing needs of realpolitik versus the rule of law, security concerns versus requirements of due process, secrecy versus transparency, discretion versus accountability, and preference for unified direction versus pluralism.

Some counterterrorism practices employed by the United States in its post-9/11 Global War on Terror have proved especially at odds with the US stated objective of advancing democratic values abroad. First, there is the ongoing practice of indefinite detention of mostly Middle Eastern terrorist suspects at the Guantanamo Bay detention facility. According to a senior UN human rights official, "the continuing indefinite incarceration of many of the detainees [in Guantanamo] amounts to arbitrary detention and is in clear breach of international law."(The World Post, 2013) Second, there were what then US Secretary of Defense Ronald Rumsfeld defined as "enhanced interrogation techniques". An Orwellian way to describe interrogation practices, such as waterboarding, sleep deprivation, and forced-feeding, that many authoritative sources, including the International Committee of the Red Cross, criticized as plain torture.(Lewis, 2004) Finally, there was a highly classified CIA program of extraordinary rendition and secret detention. We now know that the CIA program consisted in terrorist suspects being secretly flown outside the United States to be interrogated by foreign governments that used torture, or by the CIA itself in clandestine "black sites" using torture techniques.(Open Society Foundations, 2013) Although these practices clearly infringed the very values the United States claims to stand for, US officials deemed them necessary to disrupt terrorist networks and protect the nation against further attacks.

\section{The Arab Awakening as a missed opportunity}

Unexpectedly, in 2011, the Arab Awakening offered a unique opportunity to the Obama administration to advance the US strategic interest of countering terrorism without compromising the US ideal interest 


\section{Journal of Terrorism Research}

of promoting democracy. In fact, in 2011, popular uprisings across the Greater Middle East forcefully demanded more political freedom, equal economic opportunities, greater accountability of their leaders, and less corrupted political systems. The protesters' demands were in line with the US ideal interest of supporting the spread of more democratic forms of government. Meanwhile, the overwhelmingly peaceful nature of the uprisings seemed to have fatally discredited the extremists' argument that only violence could achieve meaningful change in the region.

Immediately after the outbreak of the Arab Awakening, extremist groups tried to take credit for the unrest. Al Qaeda leader Ayman al-Zawahiri, for example, claimed that the Awakening was a direct consequence of the 9/11 terrorist attacks a decade earlier.(Associated Press, 2011) Al Qaeda and other likeminded extremist groups depicted the objectives of the uprisings as in line with their rejection of the status quo in the Greater Middle East. Claims like al-Zawahiri's had no significant resonance among Middle Eastern public opinions. Despite their efforts, extremist groups had only a marginal, if any, role in the initial phases of the Arab Awakening. Indeed, political, economic, and social grievances, and not violent extremist rhetoric, were the primary reasons that had brought the protesters into the street. Egypt was a case in point: two weeks of peaceful popular protests had driven Egyptian President Hosni Mubarak out of office; a remarkable goal that extremists like al-Zawahiri had failed to achieve after decades of armed struggle. In 2011, there was reason to believe that the success of the Arab Awakening had the potential to simultaneously serve both the US ideal interest of advancing democratic values and the US strategic interest of fighting Middle Eastern terrorism. However, despite the initial enthusiasm, the Arab Awakening has hardly been a success for democracy. Four years down the road, the popular uprisings have mostly failed to answer the protesters' demands. In the countries that experienced the full-blown Awakening in 2011, democratic values have not made any significant gain. In order to provide an up-to-date assessment of the democratic record of such countries, we primarily rely on the Country Reports on Human Rights Practices (CRHRP) and the World Report (WR) issued respectively in 2014 by the US State Department's Bureau of Democracy, Human Rights and Labor and in 2015 by the non-governmental organization Human Rights Watch.(Human Rights Watch, 2015; US Department of State, 2014)

As mentioned earlier, the Egyptian uprising led to the ouster of President Hosni Mubarak. Mubarak's removal in February 2011 was welcomed as a historic step that would allow Egypt to move toward a more democratic form of government. After a transitional period of military rule, power was peacefully transferred to a newlyelected parliament in early 2012. Egyptians elected a new president and approved a new constitution later in the same year. However, the policies adopted by the new Islamist president were perceived as sectarian and divisive, and, consequently, generated a strong domestic opposition. In response to growing tensions, the Egyptian armed forces staged a coup deetat in July 2013 that removed from power the newly-elected president. Since then, with the stated objectives of combating terrorism and restoring law and order in the country, a military-backed government has undertaken a systematic crackdown on the opposition. Restrictive measures have particularly targeted the Egyptian branch of the Muslim Brotherhood. According to credible estimates, since the July coup, clashes involving state security forces and protesters have resulted in between 1,000 and 2,500 dead, more than 17,000 wounded, and between 16,000 and 19,000 arrests. The CRHRP and the WR highlight serious issues that still hinder Egypt's transition toward democracy: the excessive use of force by state security forces, including unlawful killings and torture; arbitrary arrests; the suppression of civil liberties, including societal and government restrictions on freedom of expression, press, and assembly; and impunity for state security forces.(Sharp, 2014) 


\section{Journal of Terrorism Research}

In the immediate aftermath of the ouster of Egypt's President Mubarak, a major uprising broke out in Bahrain. Bahraini protesters mainly demanded reforms aimed at establishing a constitutional monarchy. The unrest escalated quickly, especially after several protesters were killed in clashes with state security forces. Moreover, the Bahraini government's half-hearted promises of reform failed to stop the opposition from staging increasingly large demonstrations. In March, when the Bahraini authorities seemed on the verge of losing control of the country, the Gulf Cooperation Council (GCC) decided to send troops into Bahrain to shore up the embattled royal family. The GCC military intervention was followed by a harsh crackdown on dissent. Since then, the Bahraini government and the opposition have tried to reach a political solution to their differences through two national dialogues. Neither attempt (the first in July 2011 and the second from February to December 2013) was successful in stopping the continued low-intensity unrest in the country. So far, the government has enacted only modest reforms that have neither significantly diluted its authority nor addressed the demands of the opposition for a fairer distribution of political and economic opportunities. According to the CRHRP and WR, the most urgent democracy problems faced by Bahrain include: the continued discrimination against the Shiite population; the inability of Bahraini citizens to change their government peacefully; politically motivated arrests; the lack of consistent accountability for security officers accused of committing human rights violations; and restrictions on civil liberties.(Katzman, 2014)

In Yemen, a peaceful grassroots uprising demanding reforms and better living conditions progressively turned into an armed struggle for power among competing traditional elites. Only foreign diplomatic mediation temporarily stopped the country's seemingly inexorable descent into a state of all-out civil war. The GCC brokered an internationally-supported transition plan that called for Yemen's President Ali Abdullah Saleh to resign while granting him, and his inner circle, immunity from prosecution. After months of continued fighting and political jostling, the Yemeni president eventually signed the GCC plan and stepped aside in November 2011. As part of the transition plan, Yemen engaged in a comprehensive national dialogue that lasted from March 2013 to January 2014. The so-called National Dialogue Conference ended with a blueprint for far-reaching reforms. However, agreement was elusive on a number of contentious and potentially destabilizing issues, such as a power-sharing agreement between North and South and the disarmament of non-state actors. Unresolved issues led to renewed violence. At the time of this writing, Yemen's very physical integrity is threatened by an armed confrontation among a diverse array of domestic and foreign actors including Yemeni government forces (supported by a coalition of Arab states), Saleh's loyalists, the Houthi insurgency (allegedly supported by Iran), and the extremist groups Al Qaeda in the Arabian Peninsula (AQAP). Moreover, arbitrary killings and other human rights abuses perpetrated by state and non-state groups; a weak central government; the lack of civilian oversight on state security forces; and widespread corruption at all levels of government, including a corrupt judicial system that is unable to ensure the rule of law, represent persistent obstacles to Yemen's process of democratization.(International Crisis Group, 2014)

Inspired by the unrest in the region, Libyan demonstrators took to the street to protest the authoritarian and corrupt rule of Colonel Muammar Qaddafi. Confronted by significant popular opposition, Libya's central institutions quickly crumbled. The anti-Qaddafi opposition, backed by defected troops, established control over a number of cities in the east. The Libyan regime announced its intention to crash the opposition with all the means at its disposal. Ostensibly to avoid the massacre of civilians in the opposition-held city of Benghazi, the United Nations Security Council authorized foreign military intervention in support of the anti-Qaddafi forces. The ensuing armed conflict lasted for months and ended only in October 2011 with the killing of Qaddafi himself. Since then, Libyan interim authorities have failed to form a stable government 


\section{Journal of Terrorism Research}

and to assert uncontested control over much of Libya's territory. Tellingly, as of 2015, the country displays two opposing national assemblies both claiming to be the legitimate representative of the Libyan people. Additionally, Libya's eastern and western regions are plagued by continued fighting among heterogeneous coalitions of rival armed groups. The United Nations has reported the indiscriminate use of military weaponry, unlawful killings, abductions, and the internal displacement of hundreds of thousands of people during the conflict. At present in Libya, the absence of a single legitimate political authority, coupled with a marked deteriorating security situation, makes the possibility of enacting meaningful democratic reforms very unlikely.(Blanchard, 2014)

In mid-March the Arab Awakening also reached hitherto quiet Syria. Like in other Middle Eastern countries experiencing turmoil in 2011, protesters in Syria called for more freedom and democracy, better living conditions, and an end to government's corruption and unaccountability. In response to peaceful demonstrations, the regime of President Bashar al-Assad carried out mass arrests and made extensive use of lethal force. So far, the uprising in Syria has not resulted in either regime change as in Egypt, Yemen, and Libya or in a national dialogue as in Bahrain. The Syrian uprising has instead plunged the country into a protracted state of civil war that has been fought along distinct sectarian and religious lines. Although the Syrian regime has lost control of large areas of the country, President Assad has not been toppled. Moreover, within the anti-government opposition, extremist groups with radical agendas have gained the upper hand. Both Assad supporters and opposition forces have been accused of committing human rights abuses, carrying out massacres, and engaging in torture. The current situation of instability, lawlessness, and violence in Syria do not allow for any serious discussion about democratic reforms.(Blanchard \& others, 2014)

Tunisia represents the only major exception to the general democratic retrenchment occurring in the Greater Middle East. Contrary to the other "Arab Awakening" countries, in fact, Tunisia has so far avoided the traps of both armed conflict and authoritarian recrudescence. The Tunisian uprising was the first to hit the region and arguably inspired all the others. Despite relatively effective state services and strong economy, Tunisians complained about important limits to their freedom of expression, political participation, economic opportunities, and religious activism. Popular protests started in mid-December 2010 and in a few weeks led to the ouster of President Zine El Abidine Ben Ali. After Ben Ali's departure, Islamist and secular parties have competed for influence. Faced by political polarization and a stalled economy, and not without tensions and misunderstandings, the major parties among the Tunisian political spectrum have showed their willingness to compromise. In 2014, the country has adopted a new constitution, and has held relatively fair and peaceful legislative and presidential elections. The CRHRP and WR point out that Tunisia's transition to democracy is far for complete. Issues of state security forces' unaccountability and constraints on freedom of expression persist. Nevertheless, observers have acknowledged that Tunisians nowadays enjoy more civil and political liberties than they used to do in the past.(Arieff \& Humud, 2014)

Tunisia aside, the Arab Awakening has so far failed to put the Greater Middle East on a sound path toward more democratic forms of government. As the most influential foreign power in the region, the United States is to some extent responsible for such a failure. This is not to say that the United States was in a position to determine its desired outcome of the uprisings. In fact, US overall influence over the events was constrained by both external and domestic factors, including the predominantly local nature of the Arab protests, the concerns of US regional allies (Israel and Saudi Arabia were particularly wary of revolutionary political change), and US fiscal problems. These constraints aside, the Obama administration still proved reluctant to side fully with the popular uprisings, therefore denying the protesters the international backing that could have increased their chances of success. 


\section{Journal of Terrorism Research}

We distinguish the Obama administration's response to the 2011 uprisings into three distinct categories. In the first category, we group the US response to uprisings in countries where the United States had no significant national interests at stake, that is Tunisia. The second category lists the response to uprisings where the Obama administration faced a convergence between US ideal and strategic national interests, namely Libya and Syria. Finally, in the third category, we place the response to uprisings where US ideal interests conflicted with US strategic ones, specifically Egypt, Bahrain, and Yemen.

Tunisia is a peripheral country in the Greater Middle East, both in terms of its geographic location and of its political, economic, and social influence. As a consequence, Tunisia was not a top-priority for US foreign policymakers. In spite of some level of military-to-military cooperation on issues of counterterrorism, the United States had not vital strategic interest in the bilateral relationship with the Tunisian government. When unrest broke out, the Obama administration expressed concern but announced that it was "not taking sides". (Clinton, 2011) As a matter of fact, the United States played no meaningful role during the popular uprising that led to the ouster of President Ben Ali. Although US policymakers have repeatedly described Tunisia as a key test case for democratic transitions in Middle Eastern states, the country remains of marginal importance for the United States and, as such, it has received relatively little political attention.

In Libya, the Obama administration confronted a foreign policy emergency where US ideal and strategic interests converged. US officials concluded that backing the Libyan uprising would serve the US ideal interests of spreading democratic values in the Greater Middle East, protecting civilians from the brutality of an oppressive regime, and avoiding a severe humanitarian crisis. Meanwhile, US endorsement of the anti-Qaddafi opposition would contribute to the protection of a number of US strategic interests: fostering transatlantic relations, justifying the role of NATO in the $21^{\text {st }}$ century, preventing violence from spreading and destabilizing Libya's neighbors, and offering a public relations opportunity to rebut criticisms regarding the perceived US lack of support for the Arab Awakening. The US decision to decisively side with the Libyan opposition was also facilitated by the fact that, beyond some level of bilateral cooperation on counterterrorism and nonproliferation, the Obama administration had no fundamental national interest in keeping Colonel Qaddafi in power. However, US commitment to the success of the Libyan uprising ended soon after the military defeat of the Libyan regime. Deeply weary of embarking on yet another exercise of state building (especially after the recent costly experiences of Iraq and Afghanistan), the United States quickly disengaged from Libya, leaving the war-torn country plunging into a state of prolonged chaos.

At first glance, Syria also appeared to provide a case of convergence among different US national interests. In fact, the ideal interest of supporting protesters demanding more freedom, democracy, and better living conditions seemed compatible with the strategic interest of putting an end to an openly hostile regime. The Obama administration, therefore, proved initially keen to offer rhetorical support for the anti-Assad opposition and to exert economic and diplomatic pressure on the Syrian regime. With time, however, US officials became increasingly concerned about the growing influence of Islamist extremist groups within the ranks of the Syrian opposition. The US administration was caught between the understanding that the rule of President Assad had become untenable and serious concerns about the uncertainty of what would replace it. Consequently, the United States assumed a cautious policy of half-hearted support for the uprising that resulted in limited US military assistance to the Syrian armed opposition and rejections to repeated calls for direct US military intervention against Assad forces.

Egypt, Bahrain, and Yemen presented the US administration with the difficult choice of either endorsing popular uprisings demanding democratic reforms or backing friendly Arab autocrats that had proved 


\section{Journal of Terrorism Research}

instrumental to the advancement of core US strategic interests. Eventually, the Obama administration adopted the US traditional Middle East policy (described above by Indyk and Pollack) of downplaying the promotion of US ideal interests in favor of the protection of US strategic ones. Hence, concerns about the future of the 1979 Egyptian-Israeli Peace Treaty led to the hesitation with which the Obama administration belatedly decided to espouse the Egyptian protesters' call for President Mubarak's immediate resignation. Likewise, the continuing strategic importance of stationing the US Fifth Fleet in Bahrain limited the US administration's response to the Bahraini government's violent crackdown on the opposition mainly to expressions of mild criticism. Finally, US single-minded preoccupation with fighting Al Qaeda in the Arabian Peninsula shaped the US response to unrest in Yemen where the strategic interest of maintaining counterterrorism cooperation with the local government dwarfed the ideal interest of promoting democratic values.

Ensuing controversial US decisions have only strengthened the perception that the United States is not seriously committed to the cause of Arab democracy. In the aftermath of the Arab Awakening, the Obama administration proved especially keen on reestablishing business-as-usual relations with new and old Arab regimes that had responded to popular protests with increased political repression and human rights abuses. US policy toward Egypt is a case in point. Primarily concerned with maintaining cordial relations with Egypt's military leaders, the Obama administration even refused to define the Egyptian military's forced removal of a democratically-elected president in 2013 as a coup d'état; a definition, that according to US law, would have required the suspension of US bilateral aid to the country. The fact that Egyptian President Mohamed Morsi was an Islamist formerly affiliated to the Muslim Brotherhood was another important factor in the Obama administration's decision not to take a strong stand against the military coup. Influential forces both inside and outside the United States were deeply uncomfortable with the idea of Islamists ruling Egypt and, therefore, they saw no compelling reason to oppose the coup.(Esposito, 2013) Domestically, both Republicans and Democrats in the US Congress had repeatedly conveyed their skepticism about the Muslim Brotherhood's commitment to democracy. Internationally, US regional allies had also openly expressed their concerns. Israel, for example, feared that an Islamist-led Egyptian government would be more sympathetic toward the Palestinian Islamist organization Hamas and perhaps decide to loosen or terminate the blockade against the Gaza Strip. Saudi Arabia, and to a lesser extent the United Arab Emirates, worried that an empowered Muslim Brotherhood would damage their religious legitimacy by offering a model of Islamic law different from the Wahhabi tradition of an absolute monarchy. The combination of these internal and external pressures certainly influenced President Obama's response to the 2013 coup.

The resulting continued US close association with autocratic Arab regimes, and their repressive policies, has had the unwanted effect of increasing popular antipathy to the United States. Meanwhile, extremist organizations, like Al Qaeda and the Islamic State, have proved ready to exploit the widely held perception that the United States and its regional allies have systematically worked to undermine the cause of Arab democracy as a propaganda tool to advance their radical agendas.

\section{Implications for the United States}

All that considered, the events of these last few years have the potential to severely damage US current and future counterterrorism efforts in the Greater Middle East. To begin with, the hitherto failure of the Arab Awakening to significantly improve the political, economic, and social conditions of affected Arab countries has left the region open to extremist groups ready to exploit unresolved grievances, including widespread 


\section{Journal of Terrorism Research}

corruption, sectarian discrimination, high unemployment, and disregard for human rights. After that, the 2011 uprisings overwhelmingly started as peaceful protest movements. Because of the lack of meaningful success, disillusioned protesters may draw the dangerous conclusion that change in the Greater Middle East cannot be achieved by peaceful means; Arab protesters may buy into the extremists' narrative that resorting to violence is their only chance to ameliorate their lot in life. Additionally, anti-Americanism was a negligible aspect during the early phases of the Awakening. Indeed, Arab protesters were predominantly calling for reforms in line with traditional US values and ideals. However, the Obama administration's half-hearted support for the popular uprisings drew many criticisms, especially in the Greater Middle East, and it was deemed partly responsible for the eventual failure of the Arab Awakening to deliver meaningful change. In other words, the complex dynamics set in motion by the transformative events occurred since 2011 have sowed the seeds for future, wider, and possibly more anti-American, terrorist activity.

As of early 2015, clear signs of a renewed terrorist threat are already visible across the region. The proliferation of new and old extremist groups in almost every post-Arab Awakening country is hard to ignore. The Islamic State and the Nusra Front have undoubtedly emerged as two of the strongest actors involved in the Syrian civil war. Since the ouster of President Mubarak, the formation of Ansar Bayt al Maqdis has represented a persistent and challenging menace to Egypt's stability. Three distinct extremist groups, sharing the common name Ansar al Sharia, have stepped up their operations in Tunisia, Libya, and Yemen. In Yemen, AQAP remains perhaps the most dangerous of all Al Qaeda's franchises. Even in relatively-quieter Bahrain, radical opposition factions have become more organized, claiming responsibility for increasingly frequent violent actions. While these extremist groups primarily focus their attacks on local targets, US officials have identified them as credible threats to the United States or its allies, and to US national interests in the Greater Middle East.(Humud \& others, 2014)

In order to stop, and possibly reverse, this negative trend, the United States needs to thoroughly reevaluate its Middle East policy to take into account widespread popular demands for change. US officials should adopt the long view while confronting the immediate terrorist threat. In particular, a primary aspect of US policy should be to address the domestic dynamics inside Middle Eastern states that are standing on the way of the kind of durable social and political peace critical to counter the extremists' narrative.

Accordingly, action in two policy-areas becomes of paramount importance.

First, the United States should identify innovative and effective ways to leverage US bilateral assistance to promote political, economic, and social reforms in the Greater Middle East. Special attention should be given to programs aimed at fostering individual freedoms, human development, and economic opportunity as essential tools against the radicalization of Middle Eastern populations. When applicable, conditionality clauses on US assistance should be enforced without exception to avoid damaging charges of hypocrisy and double standards.

Second, the United States should commit meaningful resources to support the development and empowerment of civil society. In fact, by providing frustrated Middle Eastern people with non-violent channels to find a satisfactory solution to their longstanding grievances, domestic civic groups can represent a peaceful alternative to terrorists' violence. Moreover, domestic civic groups can also help to spread those democratic values, such as pluralism and tolerance, badly required in the long-term fight against extremism.

About the author: Eugenio Lilli obtained his PhD in 2015 at King's College London (KCL), War Studies Department. He is the founding chairperson of the KCL US Foreign Policy Research Group. His research focuses on the foreign relations of the United States and especially on the Barack Obama administration's foreign policy 


\section{Journal of Terrorism Research}

toward the region of the Greater Middle East. Eugenio has appeared on Al Jazeera's Inside Story, The Telegraph, and other national and local media outlets.

\section{References}

Arieff, A., \& Humud, C. (2014). Political Transition in Tunisia. Congressional Research Service. Retrieved from http://fas.org/sgp/crs/row/RS21666.pdf

Associated Press. (2011, September 13). Al-Qaida Leader Seeks Credit for Arab Spring. The Guardian.

Retrieved from http://www.theguardian.com/world/2011/sep/13/al-qaida-leader-arab-spring

Blanchard, C. M. (2014). Libya: Transition and U.S. Policy 08/09/2014. Congressional Research Service.

Retrieved from http://fas.org/sgp/crs/row/RL33142.pdf

Blanchard, C. M., \& others. (2014). Armed Conflict in Syria: Overview and U.S. Response 17/09/2014.

Congressional Research Service. Retrieved from http://fas.org/sgp/crs/mideast/RL33487.pdf

Bush, G. W. (2006, March 16). The National Security Strategy of the United States 2006. Retrieved from http://georgewbush-whitehouse.archives.gov/nsc/nss/2006/

Clinton, H. (2011, January 12). Clinton Tackles Tunisia, Iran, Lebanon \& Mideast Talks. Al-Arabiya.

Retrieved from http://www.alarabiya.net/articles/2011/01/12/133153.html

Esposito, J. (2013, July 25). Mubarak Redux: Egypt's Military Coup Unmasked. Huffingtonpost. Retrieved from http://www.huffingtonpost.com/john-l-esposito/mubarak-redux-egypts-mili b 3646135.html

Fulton T. Armstrong. (2002). Ways To Make Analysis Relevant But Not Prescriptive. Studies In Intelligence, 46(3). Retrieved from https://www.cia.gov/library/center-for-the-study-of-intelligence/csi-publications/csistudies/studies/vol46no3/article05.html

Human Rights Watch. (2015). World Report 2015. Retrieved from http://www.hrw.org/sites/default/files/ wr2015 web.pdf

Humud, C., \& others. (2014). Al Qaeda-Affliated Groups: Middle East and Africa. Congressional Research Service. Retrieved from http://fas.org/sgp/crs/mideast/R43756.pdf

Huntington, S. P. (1997). The Erosion of American National Interest. Foreign Affairs, 76(5).

Indyk, M. S., Lieberthal, K. G., \& O’Hanlon, M. E. (2012). Bending History: Barack Obama’s Foreign Policy. Washington DC: Brookings Institution Press.

International Crisis Group. (2014). The Huthis: From Saada to Sanaa. Retrieved from http://www.crisisgroup. org/ /media/Files/Middle\%20East\%20North\%20Africa/Iran\%20Gulf/Yemen/154-the-huthis-from-saada-tosanaa.pdf

Katzman, K. (2014). Bahrain: Reform, Security, and U.S. Policy 03/10/2014. Congressional Research Service. Retrieved from http://fas.org/sgp/crs/mideast/95-1013.pdf

Lewis, N. A. (2004, November 30). Red Cross Finds Detainee Abuse in Guantánamo. The New York Times. Retrieved from http://www.nytimes.com/2004/11/30/politics/30gitmo.html?scp=1\&sq=Tantamount\%20 to\%20torture\&st=cse

Naftali, T. (2004). US Counterterrorism before Bin Laden. International Journal, 60(1).

Nye, J. S. (1999). Redefining the National Interest. Foreign Affairs, 78(4). Retrieved from http://www. 


\section{Journal of Terrorism Research}

foreignaffairs.com/articles/55209/joseph-s-nye-jr/redefining-the-national-interest

Obama, B. (2015, February). The National Security Strategy of the United States 2015.

Open Society Foundations. (2013). Globalizing Torture: CIA Secret Detention and Extraordinary Rendition.

Retrieved from http://www.opensocietyfoundations.org/sites/default/files/globalizing-torture-20120205.pdf

Pollack, K. M. (2011). Understanding the Arab Awakening. In The Arab Awakening. Washington DC:

Brookings Institution Press.

Rose, G. (1998). Review: Neoclassical Realism and Theories of Foreign Policy. World Politics, 51(1), 144-172.

Sharp, J. (2014). Egypt: Background and U.S. Relations 05/06/2014. Congressional Research Service. Retrieved from http://fas.org/sgp/crs/mideast/RL33003.pdf

The Commission on America’s National Interests. (1996). America's National Interests. Retrieved from http:// belfercenter.ksg.harvard.edu/files/americas interests.pdf

The World Post. (2013, May 4). Navi Pillay, UN’s Top Human Rights Official, Calls For Guantanamo Closing In Wake Of Hunger Strikes. The World Post. Retrieved from http://www.huffingtonpost.com/2013/04/05/ navi-pillay-un-human-rights-guantanamo n 3020494.html

US Department of State. (2014). Country Reports on Human Rights Practices for 2013. Retrieved from http:// www.state.gov/j/drl/rls/hrrpt/humanrightsreport/index.htm? year=2013\&dlid=220348\#wrapper

Wilson, W. (1917, April 2). Speech to Congress 02/04/1917. Retrieved from http://www.firstworldwar.com/ source/usawardeclaration.htm

\section{Note}

[1] For the specific purpose of this article we use the term Greater Middle East to loosely refer to the region stretching east-to-west from Afghanistan to North Africa and north-to-south from the Levant to the Arabian Peninsula 